\title{
Tellurite Reduction in Schizosaccharomyces pombe
}

\author{
By D. G. SMITH \\ Department of Botany and Microbiology, University College London, \\ London WCI E 6BT
}

(Received 7 March 1974; revised 2 April 1974)

SUMMARY

The fission yeast Schizosaccharomyces pombe was grown in the presence of $10^{-3}$ to $\mathrm{IO}^{-6} \mathrm{M}$-sodium tellurite. Growth was inhibited by tellurite and at concentrations above $\mathrm{IO}^{-5} \mathrm{M}$ a black reduction product (probably tellurium) was visible in sedimented cells. Electron microscopy of thin sections showed the reduction product to be on a localized system of membranous vesicles forming an area about $500 \mathrm{~nm}$ in diameter. Membrane systems of this type were not seen in control cells but they possibly resulted from the degeneration of some of the mitochondria.

\section{INTRODUCTION}

Tellurite $\left(\mathrm{TeO}_{33}^{2-}\right)$ is toxic to many organisms, both prokaryotes and eukaryotes, and is used in a variety of selective bacteriological media and differential tests. The mechanism of its toxicity is not clear but it has been attributed to an interaction with SH groups, in particular with those of NAD dehydrogenases (Siliprandi, de Meio, Toninello \& Zoccarato, 197I). If an organism is able to grow in the presence of tellurite it frequently reduces the tellurite to black elemental tellurium. This is deposited within the cells and colonies appear black in colour. The deposition of elemental tellurium probably amounts to a detoxication of the tellurite.

When the yeasts Saccharomyces cerevisiae and Rhodotorula mucilaginosa are grown in the presence of $\mathrm{K}_{2} \mathrm{TeO}_{3}$ the reduction product is deposited mainly on specialized areas of endoplasmic reticulum (Corfield \& Smith, 1970). The present report concerns the effect of tellurite on the fission yeast Schizosaccharomyces pombe.

\section{METHODS}

The organism Schizosaccharomyces pombe (strain 132, National Collection of Yeast Cultures, Nutfield, Surrey) was cultivated in a liquid medium containing ( $\mathrm{g} / \mathrm{l}$ distilled water): glucose, 30; yeast extract (Oxoid), $5 ; \mathrm{KH}_{2} \mathrm{PO}_{4}, 2 \cdot \mathrm{I}$; final $\mathrm{pH} 5 \cdot 6$. Sterile solutions (I ml amounts) of $\mathrm{Na}_{2} \mathrm{TeO}_{3}(\mathrm{BDH})$ were added to $57 \mathrm{ml}$ culture medium in $250 \mathrm{ml}$ side-arm flasks, to give final concentrations of tellurite in the range of $10^{-2}$ to $10^{-6} \mathrm{M}$.

Flasks were inoculated with $2 \mathrm{ml}$ of a $48 \mathrm{~h}$ culture of $S$. pombe (giving an initial viable count of $0.17 \times 10^{7} / \mathrm{ml}$ ), shaken in a water bath at $30{ }^{\circ} \mathrm{C}$ and extinction measurements made hourly.

For electron microscopy cells were washed twice and then fixed in $\mathrm{I} \cdot 5 \%(\mathrm{w} / \mathrm{v}) \mathrm{KMnO}_{4}$ for $4 \mathrm{~h}$. After postfixing with $0.5 \%$ (w/v) uranyl acetate the sedimented material was dehydrated in tertiary butyl alcohol and embedded in Araldite. Sections were stained with alkaline lead citrate (Reynolds, 1963) before examination in a Siemens Elmiskop I electron microscope. 
Table I. Effect of tellurite on Schizosaccharomyces pombe after 28 growth

\begin{tabular}{|c|c|c|c|c|}
\hline & \multicolumn{4}{|c|}{ Concentration of $\mathrm{Na}_{2} \mathrm{TeO}_{3}(\mathrm{M})$} \\
\hline & 0 & $10^{-6}$ & $10^{-5}$ & $10^{-3}$ \\
\hline Approximate mean generation time $(\mathrm{h})$ & 3 & 9 & I I & $>11$ \\
\hline Extinction ( $\times$ dilution) & $3 \cdot 2$ & $2 \cdot 5$ & 0.7 & 0.7 \\
\hline $10^{-7} \times$ Total count $/ \mathrm{ml}$ & $5 \cdot 0$ & $4 \cdot 5$ & $\mathrm{I} \cdot 4$ & 0.43 \\
\hline $10^{-7} \times$ Viable count $/ \mathrm{ml}$ & $4 \cdot 0$ & $2 \cdot 5$ & 0.9 & 0.13 \\
\hline Viability $(\%)$ & 80 & 55 & 64 & 30 \\
\hline Average cell length $(\mu \mathrm{m})$ & $7 \cdot 7$ & $8 \cdot 7$ & $9 \cdot 4$ & $23 \cdot 6$ \\
\hline Final pH & $4 \cdot 5$ & 49 & $5 \cdot 2$ & $5 \cdot 6$ \\
\hline Colour of sedimented cells & Cream & Cream & Pale grey & Black \\
\hline
\end{tabular}

Mean generation times were determined from the extinction measurement growth curves. Viable counts $28 \mathrm{~h}$ after inoculation were made on yeast extract glucose agar and total counts were determined with a Coulter Counter model F. Cell lengths were taken from micrographs produced with a Zeiss photomicroscope using phase contrast optics.

\section{RESULTS AND DISCUSSION}

Schizosaccharomyces pombe was very sensitive to tellurite: $1 \mathrm{I}^{-6} \mathrm{M}$ slowed the growth rate markedly even though no visible reduction product was produced. Extinction measurements became meaningless with higher concentrations of tellurite $\left(\mathrm{IO}^{-3} \mathrm{M}\right)$ because the reduction product gave a falsely high reading. Various parameters of the tellurite-grown and control cultures are shown in Table $\mathrm{I}$; it can be seen that tellurite increased the generation time and decreased the viability of the cells. Total cell counts of stationary phase cultures, made with a Coulter Counter, showed only an approximately threefold increase in number in the presence of $10^{-3} \mathrm{M}$-tellurite, whereas the control culture showed a 30 -fold increase. The length of the $S$. pombe cells was increased about threefold by $\mathrm{IO}^{-3} \mathrm{M}$-tellurite and these cells also showed clearly-visible tellurium deposits when examined by light microscopy (Fig. I). Cells from the control are shown in Fig. 2. The final $\mathrm{pH}$ of the medium was also higher in the presence of tellurite.

Electron microscopy revealed that, as previously reported in budding yeasts (Corfield \& Smith, 1970), the reduction product after growth in tellurite was deposited on membranes in localized areas of the cytoplasm (Fig. 3). Several such areas, about $500 \mathrm{~nm}$ across, were found in each thin section. The apparently membranous structures on which the tellurite was reduced were never seen in untreated cells (Fig. 4) and therefore appeared to be produced in response to the tellurite: they are distinct in form from the Golgi bodies which have been reported in this yeast (Smith \& Svoboda, 1972; Kopecka, 1972) although some Golgi-like vesicles could be seen in close association. In $S$. pombe these areas of reduction are more distinct from the normal endoplasmic reticulum than was the case with the budding yeasts. It is possible that these membranous clusters result from some mitochondrial disintegration since mitochondria (of mammalian heart tissue) have been reported to be sites of tellurite reduction (Barnett \& Palade, 1957).

I am grateful for the technical assistance of Mrs L. A. McGrath and for an apparatus grant from the University of London Central Research Fund. 

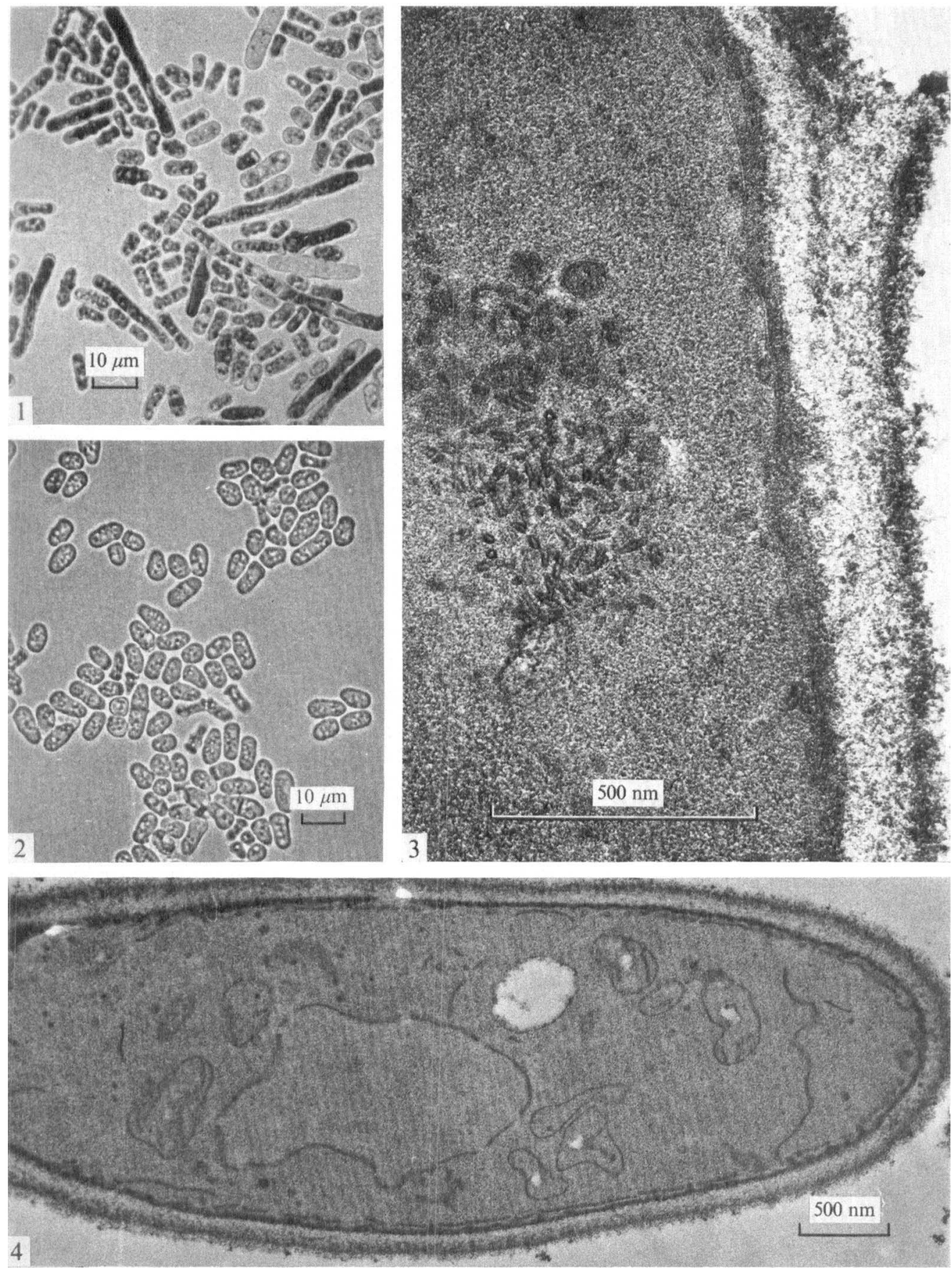

Fig. I. S. pombe after growth in the presence of $1 \mathrm{O}^{-3} \mathrm{M}$-tellurite. The cells are elongated and show black deposits of tellurium.

Fig. 2. S. pombe after normal growth in the absence of tellurite.

Fig. 3. Thin section of $S$. pombe after growth in the presence of $10^{-3} \mathrm{M}$-tellurite. Tellurium is deposited on a localized system of membranes.

Fig. 4. Thin section of $S$. pombe after growth in tellurite-free medium. 


\section{REFERENCES}

BARnett, R. J. \& PALAde, G. E. (I957). Histochemical demonstration of the sites of activity of dehydrogenase systems with the electron microscope. Journal of Biophysical and Biochemical Cytology 3, 577-588.

CORFIELD, P. S. \& SMIth, D. G. (1970). The endoplasmic reticulum as the site of potassium tellurite reduction in yeasts. Journal of General Microbiology 63, 31 1-316.

KopeckA, M. (1972). Dictyosomes in the yeast Schizosaccharomyces pombe. Antonie van Leeuwenhoek 38, 27-3I.

REYNOLDS, E. S. (1963). The use of lead citrate at high $\mathrm{pH}$ as an electron-opaque stain in electron microscopy. Journal of Cell. Biology $\mathbf{1 7}, 208-212$.

Siliprandi, D., De Meio, R. H., Toninello, A. \& Zoccarato, F. (1971). The action of tellurite, a reagent for thiol groups, on mitochondrial oxidative processes. Biochemical and Biophysical Research Communications 45, I07I-1075.

Sмrтн, D. G. \& Svoboda, A. (1972). Golgi apparatus in normal cells and protoplasts of Schizosaccharomyces pombe. Microbios $5,177-182$. 